\title{
Inbound event tourism attendees: A group qualities-values approach at destination
}

\author{
John R. Hamilton \\ College of Law Business and Governance; Division of Tropical. Environments \& Societies, \\ James Cook University, Cairns, QLD., Australia \\ Singwhat Tee and Murray C. Prideaux \\ College of Law Business and Governance, James Cook University, Cairns, QLD., Australia
}

\begin{abstract}
Purpose - The inbound event tourists drawn to an Australian destination to participate in one of fourteen annual international auto racing (AR) events can be sectioned to release each group's behavioural perspectives around their tourism-related impacts on the destination.

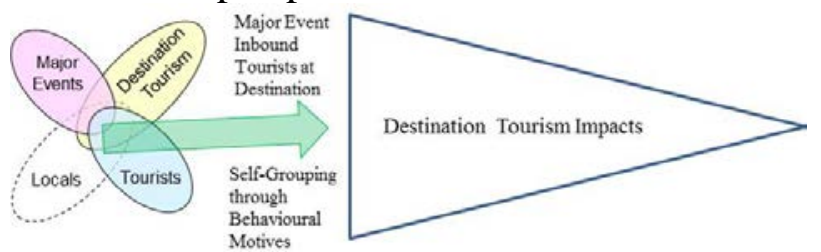

Design/methodology/approach - Inbound event tourists attending the destination are surveyed during the three day major event. Each respondent displays non-uniform, personally-driven agendas and varying degrees of local tourism acceptance.

Findings - Inbound event tourists self-select into one of six psychologically-framed AR sport groupings, and exhibit micro-differences that can then be used to align local tourism around future.

Research limitations/implications - We do not consider locals attending this international series AR event, but project their destination tourism and event impacts to be less than those of inbound event tourists. Ninety per cent of inbound AR event tourists each fit one of six motive groups and each group exhibits behaviours, decision making and spending patterns which can be later optimized in preparation for the destination's next major event.

Practical implications - AR attendees self-select into just one behavioural attendance motive. Group approaches unlock new understanding of event attendees and their behaviours. Inbound event tourists spend 2-to-1 on the destination's tourism versus its major event. Destinations targeting inbound event tourists should grow their spend ratio by bundling local tourism offerings into short length-of-stay requirements offering conservatively-priced (under \$100/activity), adventure-focused, tourism options.

Social Implications - Each inbound event tourist group displays different behavioural and spending patterns.

Originality/value - This study links inbound event tourist groupings; acquisitions; stay patterns and spending. It captures the economic components and their relative impact on the destination. By combining all the sub-groups of inbound (and local) AR event attendees, a better representation of their economic impact on the destination can be determined.
\end{abstract}

Keywords Tourism, event, auto racing, quality, value, satisfaction 


\section{Article Classification Research Paper}

\section{Introduction}

Inbound event tourism draws inbound event tourists into a destination for a particular event. These Inbound event tourists can participate in broad range of events including: food and wine; arts, culture and music; outback, nature and wildlife festivals; beach/mountain/location festivals, cultural festivals, plus sport, athletic and activity-based events/festivals (www.tourism.australia.com). Getz (2005) typologically groups these planned inbound tourism events into four main sections as: (1) cultural celebrations (festivals, carnivals, commemorations, religious events); political/state (summits, royal occasions, political events, VIP visits); arts/entertainment (concerts, award ceremonies); (2) business/trade (meetings, conventions, consumer/trade shows, fairs, markets); educational/scientific (conferences, seminars, clinics); (3) sport competition (amateur/professional, spectator/participant); recreational (fun sport/games); and (4) private events ( weddings, parties, socials). The impact of each of these location-specific events, as specific tourist drawcards, is increasingly important for the destination's ongoing competitiveness.

These inbound events are competitively designed to appeal to a range of potential event tourists, and to sufficiently motivate them to attend (Getz, 2008). Once motivated to attend, these event tourists commit to come, and whilst at the destination, they pursue their perceived (and specific) motives.

In professional inbound sport competition situations - such as in auto racing (AR), these inbound event tourists may be sectioned, or grouped, based on their attendance motives (Wann, 1995, McDonald, Milne \& Hong, 2002; Wann et al., 2008). By applying these group comparisons through an AR event, the event's (and the destination's) management and marketers can micro-interpret the requirements of these attendees. They can then further consider the specific needs of the individual attendee groups, and of the applicable destination tourism micro-markets being offered.

\section{Tourism and event attendance groups}

Hamilton, Prideaux and Tee, (2013) have established six user groups for the inbound sport event of AR. These motivational groups, established across four consecutive years of inbound event tourism research at the same destination, also align with the psychological groupings, retail shopping groupings and they fit the groupings of key sport researchers.

A major sport event at a destination is also a retail event. Here, inbound event tourists make a ticket purchase decision, turn-up, and spend. However each event tourist spends within their spheres of interest (or motivations). They also make personal choices regarding their accommodation, transport, food, entertainment, services, and tourism/products selections. These choices typically fit their social, emotional and behavioural requirements (Hamilton, Prideaux and Tee, 2011; Hamilton et al., 2013; Kim, Trail \& Magnusen, 2013), but each inbound event tourist is motivated to turn-up (Evaggelinou \& Grekinis, 1998; Wertz et al., 2011), and each fits into a variant of Arnold \& Reynolds, (2003) six retail shopping motive groups which in-turn are developed from McGuire's (1974) psychological theories.

Further, in sport Wann et al. (1999) recognize these inbound event tourists 'belong' to a sport - such as AR. McDonald et al. (2002) groups these belonging reasons under 12 sport motives, which further group for AR into very similar groupings to those of Arnold and Reynolds, (2003). Wann et al. (2008) also groups such AR tourists, and again an alignment of their eight motives 
can readily be framed into a consistent set of the same six turn-up group motives. These six groupings are now discussed.

\subsection{Six event tourist groupings}

Gratifiers hold solid personal beliefs. They attend to relieve personal stress and/or to be so absorbed in the destination's event that they forget other problems (McDonald et al., 2002). They 'treat' themselves to special occasion that aligns with their chosen agendas (McDonald et al., 2002; Arnold \& Reynolds, 2003). Hence an inbound tourism event allows them to emotively 'feel better' about themselves (Wann et al., 2008).

Adventurers are experience and/or thrill seekers who challenge themselves and pursue excitement. They remain adventurous - typically exploring and feeling the hype around new and/or stimulating things (McDonald et al., 2002; Wann et al., 2008). They also enjoy a stimulating atmosphere (Arnold \& Reynolds, 2003) and enjoy outwardly expressing their emotions (McGuire, 1974; Wann et al., 2008).

Inquirers express the desire to know and understand latest research, innovations, and performance changes across the operational realm. They seek functional explanations and so keep 'up-to-date'. They have an eye for detail and typically seek understanding of the 'fit' of specific items of interest (McDonald et al., 2002; Arnold \& Reynolds, 2003). Their inquisitive nature and their capabilities assessments extend into an appreciation of the design, beauty, grace and actionable performance capabilities associated across their various interest spheres (McDonald et al., 2002; Reynolds \& Arnold, 2006; Wann et al., 2008).

Socializers attend to have a good time. They usually attend with family and/or friends and/or other acquaintances. They share experiences and pursue fun times with their group (McDonald et al., 2002). These enjoyable interpersonal interactions (McGuire, 1974; McDonald et al., 2002; Wann et al., 2008) also build the socializer's group acceptance and impact on their personal level of satisfaction (Arnold \& Reynolds, 2003).

Valuers critically assess the inbound event and its destination choice. They believe this destination's event is capable of matching their perceived needs. They believe there is 'value' in the event's pricing and in their chosen viewing and/or seating positions. They believe there are deals they can make when pursuing certain items (Arnold \& Reynolds, 2003), and they expect, that in pursuing these deals, they can achieve personal rewards (McDonald et al., 2002; Wann et al., 2008).

Actors love role playing and they love to be seen being connected into some part of 'their adopted team' and its competitive achievements. Actors can also display aggression, but they generally do so in an entertaining manner ((McDonald et al., 2002; Wann et al., 2008). Actors also 'brag' about their past, current, and projected experiences, and/or about their roles and connections with their 'adopted team' (Hamilton et al., 2013). Actors competitively socialize (McDonald et al., 2002), and they derive personal satisfaction (Arnold \& Reynolds, 2003), and their acting allows them some escape from their daily norms (Wann et al., 2008).

\subsection{Applying event tourist groupings}

Demographics and group selection summaries are found in Tables 1 and 2 (refer Analysis and Discussion). Table 2 uses Hamilton, et al.'s (2011; 2013) groupings of AR attendees at the same event to compare the relative strength of attendees in a group year-by-year. Over $80 \%$ of all AR event respondents self-classified into one of these six groupings every year. Hence, we use these groupings in this study. 
These groupings allow event management and marketers to interpret and group target their ongoing the destination tourism approaches. These targeted and supporting tourism events should be promoted to motivate the inbound event tourist to attend and engage in both the event itself and to participate in the destination's tourism. If satisfied with their experiences, these visiting event tourists then become potential re-marketers, and hopefully then spread their positive views about the destination and its tourist offerings throughout their connecting communication circles. Thus, by convincing inbound event tourists to revisit, the destination's local tourism profile is strengthened. In addition, event tourism can be skilfully-engaged at the local level to support/drive: infrastructure; capacity; renewal; local identity; investment; and business success - thereby contributing towards the destination's competitiveness.

However, as service requirements expand changes in both lifestyle enhancements and social division occur; and as local council commitments rise, both local investment and infrastructure grow. Further, as the local economy advances, its cost of living rises; and as its tourism attractiveness rises, but its local gentrification often declines (Guerzoni, 2008). Hence, opposing circles to inbound event tourism naturally exist, but over-time these can be successfully (and stepwise) managed by addressing each issue in turn (each as an individual component of the broader and destination-specific challenges that arise when inbound events move into a local destination).

In this study we consider the inbound event tourist's destination acquisitions - those beyond the event itself. We investigate how individual inbound event tourists found out about this destination's event tourism and what local event tourism supporting activities they chose. We seek to understand what local areas are chosen, what tourism support activities these inbound event tourists prefer, what local services are reasonable, and what additions to the inbound event tourism offering are useful. We seek to define what stimulating tourism experiences are enjoyed. We also consider discretionary expenditure of six grouped event tourists - developed from the six AR groupings of Hamilton et al. (2013). We check commitment-to-return as a triangulation indicator of the event tourism attendees' qualities preferences commitments.

\section{Theoretical basis}

Based on the above, we consider whether the destination's local tourism can draw on its inbound event tourism, and over time add value to its destination as a tourist attraction.

\section{Research study}

This AR destination tourism study is conducted annually at event, and at destination, over a one week period in July. Although our studies are conducted from 2010 to 2013, we focus our attention on the 2013 study. The three day competition drew 146,842 AR attendees. After data cleaning and outlier removal, 1234 (0.84\% of attendees) valid surveys were obtained (Table 2). Inbound event tourists all live over one hour's drive $(100 \mathrm{~km})$ from the event destination, and they number 577 (Table 1). In completing their destination tourism survey each event attendee provided their demographic answers and their 5-point strongly disagree (1) to strongly agree (5) Likert scale perspectives about the destination. Surveys were conducted under university requirements, by around seventy pre-trained and well-equipped surveyors. Surveying occurred in the 25-30 minutes breaks that occur between each of the day's events.

\section{Analysis and discussion}


Table 1's demographics show males and females attend with ages above thirty predominating, and education levels being more trades oriented. Six self-grouping classifications of event tourists are shown as reasons for attending the inbound event - with adventurers and socializers predominating, and actors and self-gratifiers also being significant reasons to attend. Those pursuing value and inquiring into AR and its technical aspects attend in lesser numbers.

This inbound event of AR yields high satisfaction levels of 93\%. However a lesser number (86\%) indicate they shall revisit in 2014 (Table 1). Hence, improvement in the translation of satisfaction to revisiting is desirable. Redressing this difference for next year's AR event can reduce a projected loss of 10,866 event driven tourists. A revisitor loss of $14.7 \%(21,586)$ is projected. Hence to maintain/grow event tourist numbers, destination management and marketers must reinvent (or complement) their product suite, or risk a decline in destination tourism revenue from this inbound tourist event.

Table 1. Inbound tourist demographics for 2013

\begin{tabular}{|c|c|c|c|c|c|}
\hline Inbound Event Tourist Demographics & Total & $\%$ & Inbound Event Tourist Demographics & Total & $\%$ \\
\hline Gender (517) & & & Self-selected group choice (577) & & \\
\hline Male & 308 & $59.6 \%$ & Not indicate & 97 & $16.8 \%$ \\
\hline Female & 199 & $38.5 \%$ & Actors (role-player) & 65 & $11.3 \%$ \\
\hline Age group (511) & & & Inquirers & 19 & $3.3 \%$ \\
\hline Under 20 & 28 & $5.5 \%$ & Valuers & 29 & $5.0 \%$ \\
\hline $20-29$ & 58 & $11.4 \%$ & Adventurers & 150 & $26.0 \%$ \\
\hline 30-39 & 93 & $18.2 \%$ & Socializers & 134 & $23.2 \%$ \\
\hline $40-49$ & 141 & $27.6 \%$ & Gratifiers & 83 & $14.4 \%$ \\
\hline $50-59$ & 126 & $24.7 \%$ & Highest education (505) & & \\
\hline Over 60 & 65 & $12.7 \%$ & Secondary & 192 & $53.1 \%$ \\
\hline Overall satisfaction (577) & & & Trade & 157 & $8.2 \%$ \\
\hline Strongly Disagree & 0 & $0.0 \%$ & Diploma & 72 & $15.5 \%$ \\
\hline Disagree & 8 & $1.4 \%$ & Tertiary & 84 & $23.2 \%$ \\
\hline Neutral & 30 & $5.2 \%$ & Revisiting this event again in 2014 (468) & & \\
\hline Agree & 326 & $56.5 \%$ & Yes & 401 & $85.7 \%$ \\
\hline Strongly Agree & 213 & $36.9 \%$ & No & 67 & $14.3 \%$ \\
\hline
\end{tabular}

Around the inbound event period, the destination's management and marketers can integrate their tourism approach into a support-suite that complements the likely preferences of the AR groupings defined herein. They can approach the inbound event organizers, and seek a co-branding position - with both bodies jointly cross-promoting the inbound event as an integrated destination tourism experience. Suh, Lim, Kwak \& Pedersen (2010) suggest convenience, information, diversion, socialization, economic value, competition, winning and achievement offer joint promotional opportunities.

To maintain attendee numbers new ideas form additional inbound event tourist motivators. Here, shaded, seated, big video screen social facilities (such as circus-sized tents); mobile and tablet car racing competitions; challenges to complete new tourism activities; social network at-event forums/competitions; at-event car/component lotteries; and/or suite of visitors and locals challenges can build destination-specific and at-event-only tourist motives. Such approaches can be frames to generate positive feelings regarding the tourist's choice to visit, and to participate at the destination.

The physical and the personal consumption requirements of the event tourist can be targeted with the event promoted as a special occasion - one offering: unique merchandise such as: new and exciting experiences; fun and adventure; auto simulations and knowledge acquisition; fun family and group activities; value-for-money selections; and between-events entertainment. 
These physical acquisitions can be complemented with participatory activities each targeted at least one of the six event tourist groups attending.

Satisfaction and revisiting are event tourist decisions made about the inbound event and the local tourism when they reflect back on their expected (motives) and experienced (consumption) times at this destination. Hence raising the percentage of revisitor numbers is not a simple process.

Table 2 summarizes annual AR groupings at the same inbound event Hamilton, et al., (2013). They find attendees consistently group themselves into one preferred group, and do not select multiple groupings to best describe their reasons to attend. These groups are shown in Table 2 (and they align with Table 1's preferences). In 2013 90\% of inbound event respondents selected a group and $10 \%$ did not. Thus, this AR event should be targeted as an adventurous, socializing, and a chance to self-identify with an AR team or manufacture brand, or to act out a role as an AR or team fan. The growth in socializer numbers over the 4 years is due to a focused marketing campaign promoting social activities as a feature of the inbound event.

Table 2. Inbound tourist self-selected group choice (against no choice) for 2010 to 2013

\begin{tabular}{|c|c|c|c|c|c|c|c|c|c|}
\hline Group & 2010 & $\begin{array}{c}\text { (152,074 } \\
\text { Attendees }) \\
\text { No. of } \\
\text { Responses }\end{array}$ & 2011 & $\begin{array}{c}\text { (150,876 } \\
\text { Attendees) } \\
\text { No. of } \\
\text { Responses }\end{array}$ & 2012 & $\begin{array}{c}\text { (152,161 } \\
\text { Attendees) } \\
\text { No. of } \\
\text { Responses }\end{array}$ & 2013 & $\begin{array}{c}\text { (146,842 } \\
\text { Attendees) } \\
\text { No. of } \\
\text { Responsese }\end{array}$ & Measures \\
\hline Gratifiers & 80 & & 131 & & 139 & & 175 & & $\begin{array}{l}\text { Treat themseves to a } \\
\text { special occasion }\end{array}$ \\
\hline Adventurers & 86 & & 592 & & 384 & & 325 & & $\begin{array}{l}\text { Attend because its an } \\
\text { exciting adventure }\end{array}$ \\
\hline Inquirers & 69 & $\begin{array}{l}456 / 559= \\
81.6 \%\end{array}$ & 23 & $\begin{array}{l}1137 / 1177= \\
96.6 \%\end{array}$ & 27 & $\begin{array}{l}1057 / 1242= \\
84.7 \%\end{array}$ & 38 & $\begin{array}{l}1111 / 1234= \\
90.0 \%\end{array}$ & $\begin{array}{l}\text { Learn about the sport \& } \\
\text { keep up with latest trends }\end{array}$ \\
\hline Socializers & 74 & & 217 & & 348 & & 334 & & $\begin{array}{l}\text { Have good family/friends } \\
\text { times, meet new people }\end{array}$ \\
\hline Valuers & 69 & & 70 & & 46 & & 78 & & $\begin{array}{l}\text { View the events as value- } \\
\text { for-money }\end{array}$ \\
\hline Actors & 78 & & 104 & & 113 & & 161 & & $\begin{array}{l}\text { Enjoy pushing pers onal } \\
\text { experiences re the events }\end{array}$ \\
\hline
\end{tabular}

Table 3 sees adventurers and socializers displaying higher education levels. Adventurers and gratifiers, although satisfied show a significant tendency to refuse to revisit. This indicates they are not receiving the experiences they require. Hence these the high energy requirements of these groups now requires special consideration.

Table 3. Inbound tourist group demographics for 2013 


\begin{tabular}{|c|c|c|c|c|c|c|c|}
\hline Inbound Event Tourist Demographics & $\begin{array}{c}\text { No Group } \\
\%\end{array}$ & $\begin{array}{c}\text { Actors } \\
\%\end{array}$ & $\begin{array}{c}\text { Inquirers } \\
\%\end{array}$ & $\begin{array}{c}\text { Valuers } \\
\%\end{array}$ & $\begin{array}{c}\text { Adventurers } \\
\%\end{array}$ & $\begin{array}{c}\text { Socializers } \\
\%\end{array}$ & $\begin{array}{c}\text { Gratifiers } \\
\%\end{array}$ \\
\hline \multicolumn{8}{|l|}{ Highest education (505) } \\
\hline Secondary & 2.4 & 4.4 & 1.4 & 2.8 & 11.5 & 9.1 & 6.5 \\
\hline Trade & 2.0 & 5.1 & 2.0 & 1.6 & 7.1 & 7.5 & 5.7 \\
\hline Diploma & 1.2 & 1.8 & 0.2 & 1.0 & 4.6 & 3.4 & 2.2 \\
\hline Tertiary & 1.8 & 0.8 & 0.2 & 0.2 & 5.7 & 6.1 & 1.8 \\
\hline \multicolumn{8}{|l|}{ Revisiting the event again in 2014 (468) } \\
\hline Yes & 5.9 & 10.9 & 3.2 & 4.8 & 23.2 & 22.4 & 11.1 \\
\hline No & 0.4 & 0.8 & 0.4 & 0.6 & 4.4 & 2.8 & 4.2 \\
\hline \multicolumn{8}{|l|}{ Overall satis faction (577) } \\
\hline Disagree & 0.0 & 0.0 & 0.0 & 0.0 & 0.0 & 0.0 & 0.0 \\
\hline Neutral & 0.2 & 0.0 & 0.0 & 0.0 & 0.4 & 0.6 & 0.4 \\
\hline Agree & 1.0 & 0.8 & 0.0 & 0.4 & 0.6 & 1.8 & 1.4 \\
\hline
\end{tabular}

How respondents learned of this inbound event are highlighted in order of importance in Table 4. Interestingly, personal exchanges through word-of-mouth, and via family-and-friends remains the most important discovery process. Hence, positive inbound event, and destination tourism experiences, by all attendees remain a vital and free promotional approach. Paid traditional media advertising (TV, newspapers, radio) rate highly, but on-line sources are growing in importance. It appears that coordination in online approaches is lacking - and this area needs integrated and cross-promotional attention. The recent addition of billboards is also a useful tool if placed on key local transport routes (and within a 10 hour drive of the destination). On average event tourists find out about the inbound event via two-to-three media modes.

Table 4. Inbound event and destination discovery information by tourist for 2013

\begin{tabular}{lccccccccc}
\hline \multirow{2}{*}{ Learn of Major Event through... } & No Group & \multicolumn{2}{c}{ Actors } & Inquirers & \multicolumn{2}{c}{ Valuers } & Adventurers & Socializers Gratifiers & \multicolumn{2}{c}{ Total } \\
& $\%$ & $\%$ & $\%$ & $\%$ & $\%$ & \% & \% & No \\
\hline Word-of-mouth & 1.2 & 2.1 & 0.9 & 1.2 & 4.9 & 4.6 & 2.4 & 223 & 17.4 \\
Family/Friends & 1.2 & 1.5 & 0.5 & 0.9 & 4.1 & 5.1 & 2.6 & 205 & 16.0 \\
Free TV & 0.5 & 1.3 & 0.5 & 0.4 & 5.3 & 3.4 & 3.1 & 187 & 14.6 \\
Newspaper & 0.5 & 1.6 & 0.6 & 0.6 & 4.2 & 2.4 & 2.5 & 159 & 12.4 \\
Radio & 1.0 & 1.0 & 0.4 & 0.5 & 3.7 & 2.3 & 1.3 & 130 & 10.1 \\
Travel Agent & 0.3 & 1.3 & 0.3 & 0.4 & 2.0 & 1.9 & 1.3 & 97 & 7.6 \\
Facebook & 0.2 & 0.5 & 0.2 & 0.2 & 1.5 & 1.5 & 0.7 & 60 & 4.7 \\
Web page & 0.0 & 0.3 & 0.3 & 0.1 & 1.6 & 1.4 & 0.7 & 56 & 4.4 \\
Pay TV & 0.1 & 0.1 & 0.1 & 0.2 & 0.9 & 0.4 & 0.6 & 29 & 2.3 \\
Billboards & 0.2 & 0.3 & 0.1 & 0.1 & 1.3 & 0.7 & 0.5 & 41 & 3.2 \\
Business/Corporate promos & 0.2 & 0.3 & 0.0 & 0.2 & 1.0 & 0.3 & 0.4 & 32 & 2.5 \\
Mobile/Ipad/Phone Apps & 0.1 & 0.4 & 0.0 & 0.2 & 1.0 & 0.5 & 0.1 & 29 & 2.3 \\
Twitter & 0.1 & 0.2 & 0.0 & 0.0 & 0.3 & 0.7 & 0.2 & 19 & 1.5 \\
YouTube & 0.1 & 0.0 & 0.0 & 0.1 & 0.5 & 0.5 & 0.2 & 16 & 1.2 \\
\hline Total media used / group & 72 & 139 & 51 & 63 & 414 & 330 & 214 & 1283 \\
Total members in group & 97 & 65 & 19 & 29 & 150 & 134 & 83 & 577 \\
Av. media's used / gp member & 0.74 & 2.14 & 2.68 & 2.17 & 2.76 & 2.46 & 2.58 & 2.22 \\
\hline
\end{tabular}

Table 5 indicates the destination's supporting tourism events, and the percentages represent the percentage of the group using this event discovery approach. We note that each event tourist is asked to select all the discovery approaches they employ, and on average each only attends one-to-two extra events. The local tourism drawcards for event tourists are those relating to action tourism, those local activities with no (or low) entrance fees, or those activities connected 
to the event itself. However, all destination tourism activities provide local tourism exposure. Further, list of destination support activities for this inbound event can be extended with a combined vintage cars and AR cars display/demonstration evening, as well as other event-linking local tourism ideas.

Table 5. Destination support events on offer to inbound tourist for 2013

\begin{tabular}{lccccccccc}
\hline \multirow{2}{*}{ Support Tourism for Major Event } & No Group & \multicolumn{3}{c}{ Actors } & \multicolumn{3}{c}{ Inquirers } & \multicolumn{3}{c}{ Valuers } & Adventurers & Socializers Gratifiers & \multicolumn{2}{c}{ Total } \\
& $\%$ & $\%$ & $\%$ & $\%$ & $\%$ & $\%$ & $\%$ & No & $\%$ \\
\hline Event's other auto activities & 2.1 & 5.2 & 1.5 & 2.4 & 13.3 & 10.1 & 5.5 & 338 & 40.2 \\
National Football Game & 1.9 & 2.5 & 1.2 & 1.4 & 5.6 & 4.3 & 2.3 & 161 & 19.2 \\
Local Markets & 1.1 & 0.8 & 0.2 & 1.0 & 4.9 & 3.9 & 1.8 & 115 & 13.7 \\
Destination Welcome Day & 0.2 & 1.9 & 0.4 & 0.6 & 3.0 & 1.9 & 0.8 & 74 & 8.8 \\
Superboats Race & 0.5 & 1.3 & 0.5 & 0.4 & 2.5 & 0.7 & 0.2 & 51 & 6.1 \\
Regional Show & 0.6 & 0.8 & 0.1 & 0.1 & 1.3 & 1.3 & 0.6 & 41 & 4.9 \\
Gallery Exhibitions & 0.1 & 0.1 & 0.0 & 0.4 & 0.8 & 1.0 & 0.1 & 21 & 2.5 \\
Dance Festival & 0.2 & 0.2 & 0.0 & 0.1 & 0.7 & 0.5 & 0.1 & 16 & 1.9 \\
Chamber Music Festival & 0.1 & 0.4 & 0.0 & 0.0 & 0.7 & 0.2 & 0.0 & 12 & 1.4 \\
Vintage Car Rally & 0.0 & 0.2 & 0.0 & 0.0 & 0.2 & 0.6 & 0.2 & 11 & 1.3 \\
\hline Total tours / group & 58 & 114 & 33 & 53 & 278 & 206 & 98 & 840 \\
Total members in group & 97 & 65 & 19 & 29 & 150 & 134 & 83 & 577 \\
Total tours / gp member & 0.60 & 1.75 & 1.74 & 1.83 & 1.85 & 1.54 & 1.18 & 1.46 \\
\hline
\end{tabular}

Tables 6 and 7 give the key timing of when to activate the destination tourism supporting a inbound event. Clearly destination visitors are dedicating limited timespans to their visit. Most event tourists stay 2 or 3 days before and leave at the end of the inbound event or leave one night after. Thus most stay beyond 3 days - typically arriving the week before and leaving within 5 to 7 days. By the $8^{\text {th }}$ day $79 \%$ of the inbound event tourists have left. Thus, destination tourism should focus across the four days lead-up to the 3 day event, the event itself, and the day following the event's closure. Hence, a frenzy promotion the week before the inbound event should drive adventure, social, and group-identifying destination tourism activities at each event tourist (and also at the local AR attendees!).

Table 6. Inbound tourist stay times beyond inbound event for 2013

\begin{tabular}{|c|c|c|c|c|c|c|c|c|}
\hline \multirow{2}{*}{\multicolumn{2}{|c|}{ Days stay at Destination }} & No Group & Actors & Inquirers & Valuers & Adventurers & Socializers & Gratifiers \\
\hline & & No. & No. & No. & No. & No. & No. & No. \\
\hline \multirow[t]{7}{*}{ Nights before } & 1 & 13 & 12 & 8 & 5 & 47 & 36 & 21 \\
\hline & 2 & 11 & 14 & 1 & 4 & 25 & 22 & 12 \\
\hline & 3 & 5 & 4 & 3 & 3 & 13 & 17 & 9 \\
\hline & 4 & 3 & 6 & 1 & 2 & 7 & 11 & 7 \\
\hline & 5 & 0 & 2 & 0 & 2 & 3 & 4 & 4 \\
\hline & 6 & 1 & 3 & 0 & 0 & 5 & 3 & 1 \\
\hline & 7 & 2 & 3 & 0 & 2 & 2 & 2 & 5 \\
\hline \multirow[t]{7}{*}{ Nights after } & 1 & 16 & 16 & 8 & 6 & 51 & 42 & 26 \\
\hline & 2 & 8 & 10 & 3 & 6 & 14 & 13 & 5 \\
\hline & 3 & 0 & 2 & 2 & 1 & 6 & 4 & 5 \\
\hline & 4 & 1 & 1 & 0 & 0 & 4 & 2 & 1 \\
\hline & 5 & 0 & 1 & 0 & 0 & 2 & 3 & 0 \\
\hline & 6 & 0 & 0 & 0 & 1 & 1 & 0 & 1 \\
\hline & 7 & 1 & 4 & 0 & 0 & 1 & 3 & 1 \\
\hline Total No's in Gro & 97 & 65 & 19 & 29 & 150 & 134 & 83 & 577 \\
\hline
\end{tabular}


Table 7. Inbound tourist stay timespan for 2013

\begin{tabular}{|c|c|c|c|c|}
\hline Nights stay & $\begin{array}{c}\text { No.'s } \\
\text { staying }\end{array}$ & $\begin{array}{l}\text { Cumulative } \\
\% \text { staying }\end{array}$ & At destination & $\begin{array}{l}\text { No. } \\
\text { tourists }\end{array}$ \\
\hline 3 & 175 & 30 & on your own & 24 \\
\hline 4 & 50 & 39 & with family & 276 \\
\hline 5 & 112 & 58 & with friends & 112 \\
\hline 6 & 63 & 69 & with family \& friends & 92 \\
\hline 7 & 53 & 79 & & \\
\hline 8 & 41 & 86 & & \\
\hline 9 & 30 & 91 & & \\
\hline 10 & 14 & 93 & & \\
\hline 11 & 8 & 95 & & \\
\hline 12 & 7 & 96 & & \\
\hline $13+$ & 24 & 100 & & \\
\hline
\end{tabular}

Tables 8 and 9 show local tourism can direct its attention to considering how to target its chosen groups of event tourists. Such new tourism activities should focus on discovery and learning, and these can be combined with interest, uniqueness-and-fun, and where possible - be motor or sport related.

The appeal of the destination's local tourism can also be gauged by the event tourists' degree of discretionary spending across the destination (and beyond their spending on the inbound event itself). Table 9 shows adventurers and socializers are the highest participants in local destination tourism activities. Table 10 shows this expenditure as gauged against local accommodation, transport, attraction visits, food and drinks, gifts, souvenirs, and the like. Table 10 shows socializers actors, adventurers and gratifiers spend most at the destination. Thus, a profile of event tourist spending drivers is available for local management and marketers to assess, and to then use as possible targets for additional future destination tourism drawcards.

By converting Table 10's average spend to total group spends, and by converting these for inbound event tourist numbers, then adding special-facilities spends, and factoring for families and friends combined spends, and then multiplying by the destination's economic multiplier, the event tourist's economic value to the destination can be calculated. In this instance, the destination benefits in excess of \$36M - and only across a two week timespan! This knowledge then allows local management and marketers to plan their future approaches towards their local destination tourism, and to directly advice (and support) local tourism operators, and then to assist in the target marketing for the next inbound event - specifically targeting each specific group - based on the group numbers expected (rather than at the less concise overall event tourist level).

Table 8. Inbound tourist participation for 2013 


\begin{tabular}{lccccccc}
\hline \multirow{2}{*}{ Destination Appreciation } & No Group & Actors & Inquirers & \multicolumn{2}{c}{ Valuers } & Adventurers & Socializers Gratifiers \\
& No. & No. & No. & No. & No. & No. & No. \\
\hline Learnt new things re destination & 36 & 51 & 15 & 20 & 120 & 111 & 60 \\
Obtained sufficient interesting info re destination & 36 & 49 & 16 & 19 & 119 & 108 & 57 \\
Enjoyed destination's tropical lifestyle & 37 & 51 & 14 & 22 & 126 & 114 & 66 \\
Visited historical \& cultural attractions/events & 33 & 45 & 13 & 19 & 116 & 106 & 58 \\
Enjoyed a unique tourism experiences & 36 & 47 & 15 & 19 & 120 & 110 & 60 \\
Enjoyed fun of other destination support events & 35 & 47 & 15 & 20 & 121 & 110 & 65 \\
\hline
\end{tabular}

Table 9. Inbound tourist acquisitions for 2013

\begin{tabular}{lccccccc}
\hline \multirow{2}{*}{ Destination Tourism } & No Group & Actors & Inquirers & Valuers & Adventurers & Socializers & Gratifiers \\
& No. & No. & No. & No. & No. & No. & No. \\
\hline Discover new things about destination & 41 & 52 & 16 & 24 & 129 & 109 & 69 \\
Expand my knowledge about about places I visit & 40 & 50 & 16 & 24 & 128 & 111 & 70 \\
Do exciting and unique activities & 40 & 50 & 16 & 23 & 128 & 110 & 69 \\
Visit historical attractions and events & 37 & 49 & 13 & 23 & 129 & 109 & 67 \\
Visit cultural attractions and events & 34 & 48 & 15 & 22 & 126 & 106 & 62 \\
Be surprised with different activities & 38 & 51 & 15 & 23 & 127 & 111 & 66 \\
\hline
\end{tabular}

Table 10. Inbound tourist destination spending for 2013

\begin{tabular}{|c|c|c|c|c|c|c|c|}
\hline \multirow{2}{*}{ Destination Spending } & \multicolumn{7}{|c|}{ Event Tourist Attendee Group Av. Spends (\$/Tourist) } \\
\hline & No Group & Actors & Inquirers & Valuers & Adventurers & Socializers & Gratifiers \\
\hline Accommodation & 64 & 123 & 82 & 77 & 102 & 121 & 91 \\
\hline Café/restaurant expenditure & 43 & 93 & 88 & 85 & 90 & 97 & 84 \\
\hline Local entertainment (not support events) & 35 & 88 & 85 & 72 & 84 & 87 & 68 \\
\hline Tourist attractions & 40 & 93 & 87 & 51 & 69 & 70 & 74 \\
\hline Local support events expenditure & 30 & 79 & 99 & 80 & 60 & 62 & 60 \\
\hline Drinks at bars, hotels or nightclubs & 33 & 66 & 67 & 47 & 63 & 87 & 73 \\
\hline Local support event merchandise & 16 & 52 & 46 & 46 & 39 & 40 & 29 \\
\hline Tickets to other local activities or tours & 12 & 33 & 33 & 27 & 26 & 37 & 32 \\
\hline Local souvenirs & 15 & 27 & 29 & 18 & 22 & 23 & 20 \\
\hline Food/drinks at grocery or other shops & 13 & 25 & 32 & 17 & 8 & 23 & 22 \\
\hline Car hire & 16 & 24 & 0 & 4 & 13 & 24 & 14 \\
\hline Car-related components & 18 & 20 & 10 & 6 & 9 & 15 & 9 \\
\hline Public transport & 5 & 18 & 16 & 9 & 8 & 12 & 7 \\
\hline Major Event Spend & 167 & 349 & 355 & 316 & 342 & 368 & 336 \\
\hline Total \$ Spend on Tourism & 4,167 & & & & & & \\
\hline Total \% Spend on Tourism & $65 \%$ & & & & & & \\
\hline Total \$ Spend at Event & 2232 & & & & & & \\
\hline Total \% Spend at Event & $35 \%$ & & & & & & \\
\hline
\end{tabular}

\section{Implications of research}

\subsection{Theoretical implications}

The six psychologically, retail and sport established groups do represent the mix of AR attendees - as over 90\% of 2013 inbound event tourists self-select just one behavioural attendance motive.

Thus major event inbound tourist research can apply these multi-group study approaches to other sport events or to other areas including cultural celebrations; political/state summits/events; arts/entertainment/festivals; business/trade conventions/fairs; private events; recreational pursuits; and educational/scientific conferences/seminars. Combined with good data capture and 
analysis this can unleash new capabilities for local tourism management and/or marketers when targeting where best to pursue future inbound tourism markets.

\subsection{Practical implications}

Our analysis indicates inbound event tourists’ spending is widely spread across Table 10, with around $65 \%(\$ 24.7 \mathrm{M})$ of budget allocated to tourism related activities. The remaining 35\% (\$13.3M) is allocated to the inbound event tourist's event-specific consumption. This 2 (tourism) to 1 (event) spend ratio indicates a substantive untapped economic potential is yet to be realized by destination tourism managers and marketers. For example by linking length-of-stay with spending-behaviour, destination tourism managers and marketers have the tools to better bundle and further value-add both to their product suites and to their services offerings.

Table 10, and other variables discussed herein, can be developed into to event-specific, destination-specific, economic impact measures. These figures can be used to negotiate additional financial support from business and/or government. From repeated annual event-specific and destination-specific studies, an intelligent target mapping of the best ongoing value solutions can be determined.

\section{Future research}

\subsection{Measurement aspects}

The measurement and understanding of inbound event tourist activities for each of the six psychologically established motive groups defined herein can be behaviourally interpreted to determine the psychological decision-making process stages around each group's tourism attendance and revisiting motives, and by linking these behaviours with inbound tourist spending patterns the optimization destination revenue streams is achievable.

\subsection{Theoretical aspects}

As ten per cent of major event attendees either do not select a group or multi-select into several groups, there may be another behavioural motive that has not yet been captured across our multi-years of major sport event group determinations/developments. A good starting point for event psychology pursuits is through the reconsideration of each of McGuire's (1974) sixteen psychological behaviour theory areas, and combining these with sport psychology study approaches such as those of McDonald et al. (2002) and Hamilton, Tee and Prideaux, (2014).

\subsection{Management aspects}

Managers and marketers can capture multi-level target marketing knowledge about the effects of a major event on their destination and its tourism related operations. By representatively surveying at the event, then separating the inbound event tourists using self-selecting groupings, and then by cross referencing their demographics, marketing, support events, behaviours and the average group spends a more precise economic impact than can be obtained through the normal homogeneous at event studies. Thus, in economic terms, future events can be more precisely target-planned for inbound event tourists.

\section{Conclusions}

This study shows benefits remain in ensuring local destination studies are considered as integral parts of a major inbound event such as AR. We consider the tourism-related impacts on the destination and indicate where external revenue can be best generated from these inbound event 
tourist visitors. Thus destination tourism management and marketers can consider their where (and what) local tourism is suitable to support their next major inbound event.

We do not consider local attendees, but we project that during the event their local group impact as spend effects on destination tourism (and across the event's offerings) are less than those of their corresponding inbound event tourist groups.

Ninety per cent of inbound AR event tourists drawn to an Australian destination to participate in one of fourteen annual international AR events choose to self-select into one of six behavioural groups.

Each inbound event tourist behavioural group shows differences (Tables 1 to 5 and 8 to 10) and each group meets makes selections in-line with group-specific (behavioural and product/service-specific) spend agendas. Hence, at the destination, behavioural-decision-making and optimization targeting patterns can be refined prior to the next major event at the destination.

This study's comparative measurement tables work in tandem - indicating pathways that allow local tourism to co-brand, to co-promote, and to target market and appeal to specific inbound attendance groups coming to the major event (such as AR). For example, each inbound event tourist only engages with two or three knowledge/excitement/uniqueness tourism attractions, and typically only spends around seventy dollars per activity.

To move the average inbound event tourist's spend ratio higher (above one hundred dollars) per activity the destination should bundle its local tourism offerings into eight key days (spanning the four days prior to the event, the evenings of the three days during the event and the one day after the event). During this short length-of-stay the inbound tourist's preferred destination tourism activities (such as adventure-focused - informative, exciting, unique) should be strongly promoted by destination tourism managers and marketers.

Our simple economic approach combines all the sub-groups of inbound event tourists and provides a closer representation of their actual economic impact on the destination. The same process can be applied to local event attendees, and the major events economic impact on the destination can also be determined. This data collation across this study allows local destination tourism management and marketers to devise ongoing destination support strategies - ones that likely complement, and add value to the event itself.

\section{References}

Arnold, M.J. and Reynolds, K.E. (2003), “Hedonic shopping motivations”, Journal of Retailing, Vol. 79 No. 2, pp.77-95.

Evaggelinou, C. and Grekinis, D. (1998). “A survey of spectators at the International”, Stoke Mandeville Wheelchair Games. Adapted Physical Education Quarterly, Vol. 15, pp. 25-35.

Getz, D. (2005). Event management and event tourism (2nd ed.). Cognizant, New York, NY.

Getz, D. (2008). “Event tourism: Definition, evolution, and research”, Tourism Management, Vol. 29 No. 3, pp. 403-428.

Guerzoni, G. (2008). “The economic impact of the festival Della Mente in Sarzana”, Local Autonomies and Social Services, Vol. 2 No. 8, pp. 225-234.

Hamilton, J.R., Prideaux, M.C. and Tee, S. (2011). "Monitoring sporting groups: A sports event satisfaction study", $11^{\text {th }}$ International Conference of Electronic Business, Bangkok, Thailand, $29^{\text {th }}$ Nov-2 ${ }^{\text {nd }}$ Dec, National Chengchi University, Vol. 11 No. 1, pp. 50-53.

Hamilton, J.R., Prideaux, M.C. and Tee, S. (2013). "Linking car racing expectations and value with satisfaction, trust and loyalty outcomes", $12^{\text {th }}$ International Decision Sciences Institute and $18^{\text {th }}$ Asia-Pacific Decision Sciences Institute Conference, Nusa Dua, Bali, Indonesia, $9^{\text {th }}-13^{\text {th }}$ July, Vol. 12 No. 1 , pp. 875-888. 
Hamilton, J.R., Tee S. and Prideaux, M.C. (2014). "Gauging major auto racing event tourists at a regional destination”, Event Management, In Press (Vol. 18 No. 4, pp. 1-16).

McDonald, M.A., Milne, G.R. and Hong, J.B. (2002). "Motivational Factors for Evaluating Sport Spectator and Participant Markets”, Sport Marketing Quarterly, Vol. 11 No. 2, pp. 100-111.

McGuire, W. (1974). Psychological motives and communication gratification. In J.F. Blumer \& Katz (Eds.), The uses of mass communication: Current progression on gratification research. (pp. 106-167). Beverly Hills, CA: Sage.

Suh, Y.I. Lim, C., Kwak D.H. and Pedersen P.M. (2010). “Examining the psychological factors associated with involvement in fantasy sports: An analysis of participants' motivations and constraints”, International Journal of Sport Management, Recreation and Tourism, Vol. 5, pp. 1-28.

Kim, Y.K., Trail, G.T. and Magnusen, M.J. (2013). “Transition from motivation to behaviour: examining the moderating role of identification (ID) on the relationship between motives and attendance”, International Journal of Sports Marketing \& Sponsorship, Vol. 14 No. 3, pp. 190-211.

Wann, D. L., Schrader, M. P. and Wilson, A. M. (1999). "Sport fan motivation: Questionnaire validation, comparisons by sport, and relationship to athletic motivation”, Journal of Sport Behavior, Vol. 22, pp. 114-139.

Wann, D. L. (1995). Preliminary validation of the Sport Fan Motivation Scale. Journal of Sport and Social Issues, 19(4), 377-396.

Wann, D. L., Grieve, F. G., Zapalac, R. K. and Pease, D. G. (2008). "Motivational profiles of sport fans of different sports”, Sport Marketing Quarterly, Vol. 17 No. 1, pp. 6-19.

Wertz, F.J., Charmaz, K., McMullen, L., Josselson, R., Anderson, R. and McSpadden, E. (2011). Five ways of doing qualitative analysis: Phenomenological psychology, grounded theory, discourse analysis, narrative research, and intuitive inquiry. Guilford, New York, NY.

\section{About the Authors Authors' Backqrounds}

\begin{tabular}{|l|l|} 
& $\begin{array}{l}\text { Dr. John R. Hamilton researches competitiveness, innovation and } \\
\text { strategic futures. He has extensive corporate national (and } \\
\text { international) leadership and management experience. He } \\
\text { consults on online and/or offline engaging interactive } \\
\text { environments, and develops capabilities for business-consumer } \\
\text { real-time interfacing. Current research interests include: } \\
\text { leadership, value-deliverance, social networks, corporate and } \\
\text { virtual intelligences, cloud business scenarios, major-events } \\
\text { management, tracking, and interactive learning. John's } \mathbb{A}^{\text {ccute Euves }} \\
\text { Acute Futures Group (AcuteFutures.com) deploys international } \\
\text { R\&D task teams (Norway, Hong Kong, Singapore, and Australia). } \\
\text { Acute Futures unique value-deliverance systems create } \\
\text { custom-built experiential skilling scenarios for global and } \\
\text { futures-focused organizations. }\end{array}$ \\
\hline
\end{tabular}




Dr. SingWhat Tee is the Head of Information Systems at James
Cook University. He researches the impacts of information systems
on global citizens and their environments. His research focuses on
the criticality of operational data, value analysis, and
decision-making information systems. Current research interests
include: modelling organizational systems; intelligent
data/information modelling, social networks, and the new
information technologies systems that influence knowledge
transfer and experiential learning.

